\title{
Effects of Long-term Graded L-arginine Supply on Growth Development, Egg Laying and Egg Quality in Four Genetically Diverse Purebred Layer Lines
}

\author{
Marc-Alexander Lieboldt ${ }^{1}$, Ingrid Halle ${ }^{1}$, Jana Frahm ${ }^{1}$, Lars Schrader ${ }^{2}$, \\ Steffen Weigend ${ }^{3}$, Rudolf Preisinger ${ }^{4}$ and Sven Dänicke ${ }^{1}$ \\ ${ }^{1}$ Institute of Animal Nutrition, Federal Research Institute for Animal Health, Friedrich-Loeffler-Institut (FLI), \\ Bundesallee 50, Braunschweig 38116, Germany \\ ${ }^{2}$ Institute of Animal Welfare and Animal Husbandry, Federal Research Institute for Animal Health, FLI, \\ Dörnbergstraße 25-27, Celle 29223, Germany \\ ${ }^{3}$ Institute of Farm Animal Genetics, Federal Research Institute for Animal Health, FLI, \\ Höltystraße 10, Neustadt-Mariensee 31535, Germany \\ ${ }^{4}$ Lohmann Tierzucht GmbH, Am Seedeich 9-11, Cuxhaven 27472, Germany
}

\begin{abstract}
The present study was conducted to examine effects of long-term graded L-arginine supply on growth development, egg laying and egg quality in four genetically diverse purebred layer lines. The study comprised a rearing trial from hatch to week 16 and a following laying performance trial from week 17 to 41 . After hatch 150 oneday-old female chicks of each genotype were distributed to three diets. The experimental diets were equivalent to 70 , 100 and 200\% L-arginine of age-specific recommended level (National Research Council, 1994) and were offered ad libitum to chicks (hatch to week 7), pullets (week 8 to 16) and hens (week 17 to 41). However, hens' diets were quite low in crude protein. After a pre-laying period from week 17 to 21 thirty-six pullets of each group were used further in the laying performance trial. Independent of chicken's genetic background, insufficient L-arginine supply caused lower body weight, daily weight gain and daily feed intake during the rearing $(p<0.001)$ and induced lower laying intensity and daily egg mass production in the laying period $(p<0.05)$. Parameters fitted to Gompertz function suggested higher adult body weight in L-arginine supplemented birds compared to insufficient supplied ones $(p<$ 0.01). Groups fed with insufficient L-arginine reached age of maximum daily weight gain later and showed lowest maximum daily weight gain $(p<0.001)$. As a consequence of limitations in dietary L-arginine and crude protein, high performing genotypes decreased strongly in body weight, daily feed intake and performance compared to the low performing genotypes. In conclusion, L-arginine modified the amount of weight gain and feed intake, especially in growing chicks and pullets independent of genetic background. The high performing hens were more nutritionally stressed than the low performing ones, because concentrations of dietary crude protein were relatively low.
\end{abstract}

Key words: egg quality, genotypes, Gompertz equation, growth, laying performance, L-arginine

$$
\text { J. Poult. Sci., 53: 8-21, } 2016
$$

\section{Introduction}

L-arginine (Arg), an essential amino acid in poultry, plays a decisive role in multiple physiological processes like growth and feathering, and serves as precursor of proteins, creatine, polyamines, L-proline, various hormones and nitric oxides (reviewed in: Khajali and Wideman, 2010). Nitric

Received: April 10, 2015, Accepted: June 9, 2015

Released Online Advance Publication: July 25, 2015

Correspondence: Dr. I. Halle, Institute of Animal Nutrition, Federal Research Institute for Animal Health, Friedrich-Loeffler-Institut, Bundesallee 50, 38116 Braunschweig, Germany. (E-mail: ingrid.halle@fli.bund.de) oxides serve multiple functions in immune system (Kwak et al., 2001; Tayade et al., 2006), vasomotory regulation (Lorenzoni and Ruiz-Feria, 2006; Tan et al., 2006) and nervous system (Gaskin et al., 2003; Farr et al., 2005). Due to avian uricotelism and its underlying functionally incomplete urea cycle (Tamir and Ratner, 1963), chickens are unable to synthesize Arg de novo, highly depend on dietary Arg, and have an absolute Arg requirement. Kwak et al. (1999, 2001) describe that metabolisable plasma Arg is directly influenced by dietary Arg. The required magnitude depends on a large variety of environmental factors like bird's age and feather coverage (Bequette, 2003), source of 
dietary protein (Burton and Waldroup, 1979; Cuca and Jensen, 1990), imbalances between dietary amino acids (Keshavarz and Fuller, 1971a; Chamruspollert et al., 2004, Jahanian, 2009) as well as ambient temperatures and stressful conditions (Brake et al., 1998; Srinongkote et al., 2004).

Apart from environmental factors, nutrient utilization and metabolism are also affected by genetic influences (Simopoulos, 2002). As feather protein contains high amounts of Arg and glycine (Block, 1939), Hegstedt et al. (1941) find different Arg requirements between White Leghorn and Barred Plymouth Rock chicks in the first weeks of age due to their diverse rapidity in feathering. White Leghorns show further a diverse Arg utilization and requirement for physiological functions due to genetic divergence in lysine (Lys) metabolism (Nesheim and Hutt, 1962; Hutt and Nesheim, 1966).

Several authors associate selection with undesirable sideeffects such as deficiencies in physiological, immunological and reproduction traits (Miller et al., 1992; Liu et al., 1995; Rauw et al., 1998), and consider selection for high production efficiency as process that exacerbates genetically determined differences in nutrient requirements between genotypes (GTs). Due to genetic adaptation, metabolic resources have to be optimally distributed between maintenance to cope with the environment in which animals are kept, and production traits (Beilharz et al., 1993). Because selection aims at minimizing metabolic resources not needed for maintenance, van der Waaij (2004) and Mirkena et al. (2010) hypothesized that high performing genotypes (HPGTs) have a reduced capacity to compensate unexpected environmental changes like nutritional limitations and imbalances compared to low performing genotypes (LPGTs).

Adapting this hypothesis we conducted a long-term study from hatch to the end of $41^{\text {st }}$ week of age with four GTs of purebred layer lines differing in phylogenetic origin and performance. Different grades of dietary Arg served as nutritional-environmental stress factor during the entire trial. The objective was to examine long-term effects of dietary Arg interacting with chickens' GTs on growth development and performance.

\section{Materials and Methods}

\section{Experimental Design and Diets}

The used animal model has been described by Lieboldt et al. (2015) previously. Four purebred layer lines differing in performance and phylogenetic origin were examined. Two commercial HPGTs (WLA and BLA) taken from breeding programme of Lohmann Tierzucht $\mathrm{GmbH}$ were contrasted to two LPGTs (R11 and L68). The latter ones were maintained as non-selected resource populations at the Institute of Farm Animal Genetics in Mariensee. Both white layer lines (WLA and R11) were of White Leghorn origin and phylogenetically closely related, but distant from the Rhode Island Red higher performing BLA and its low performing counterpart L68 (New Hampshire).

In order to guarantee animal welfare and practicability for the several months lasting trial purified diets were not appropriate to offer. Due to its low Arg content corn gluten meal served as main protein source in the experimental diets (Table 1). According to the recommendations of the National Research Council (NRC, 1994) three experimental diets were calculated for the age-groups chicks and growers (hatch to week 7), growers and pullets (week 8 to 16) and laying hens (week 17 to 41) each. The diets of each agegroup comprised a basal diet with no Arg supplementation (low Arg, LA), a low Arg (adequate Arg, AA) and a high Arg supplemented diet (high Arg, HA). The basal diet was supplemented with any deficient essential amino acid other than Arg. For AA and HA, L-arginine (free base, crystalline, $99 \%$, Europepta, Hannover, Germany) was added to the basal diet in place of corn. The diets were equivalent to 70,100 and $200 \%$ Arg of the recommended level (NRC, 1994), respectively. With reference to immunonutritional Arg research (Kwak et al., 1999, 2001; Tayade et al., 2006; Tan et al., 2014), we regarded these graded dietary Arg concentrations as well-suited for further immunological research in the reared chickens.

All procedures conducted in this study were in accordance with the guidelines issued by the German animal protection law and were reviewed and approved by the relevant authorities (Lower Saxony State Office for Consumer Protection and Food Safety, LAVES, Germany; 3392 42502-0413/1186).

\section{Rearing Trial}

After hatch 150 female one-day-old chicks of each GT were equipped with individual wing-tags, vaccinated against MD and ND, and distributed to the three diets (Table 1) for chicks and growers for the first seven weeks (12 experimental groups). Afterwards groups were fed with corresponding diets for growers and pullets from week 8 to 16 . Light was provided for 24 hours on day 1 and 2. From day 3 onwards light was reduced to 15 hours daily in the first week of age. From week 1 to 7 daily light period was shortened stepwise by one hour a week to 9 hours and maintained until the end of rearing. Temperature programme followed usual specifications of chickens reared for laying. Chicks of each group $(n$ $=50$ ) were housed in five floor-range pens of ten chicks each, equipped with nipple drinkers and feeding trough. Feed and water were provided ad libitum during the entire trial. Chicks were weighed once a week from hatch to week 4 and body weight (BW) was recorded every second week from week 6 to 16 . Residual feed was recorded weekly. Daily weight gain (DWG), daily feed intake (DFI), and feed conversion ratio (FCR) were calculated on basis of recorded data.

\section{Performance Trial of Laying Hens}

At the end of rearing, thirty-six 17-week-old pullets of each experimental group were moved to a layer facility. Each group was allocated to one pen of a floor-range system equipped with a feeding trough, nipple drinkers, perches, scratch area, deep pit and nests. According to the rearing trial, corresponding hen diets with graded Arg were fed further to hens of each group from week 17 onwards (Table 1). Feed and water were provided ad libitum. From $17^{\text {th }}$ week of age onwards daily light duration was increased by 
Table 1. Composition, analysed and calculated nutrient contents of the experimental diets

\begin{tabular}{|c|c|c|c|c|c|c|c|c|c|}
\hline \multirow{2}{*}{$\begin{array}{l}\text { Ingredients } \\
\text { ( } \mathrm{g} / \mathrm{kg} \text { diet })\end{array}$} & \multicolumn{3}{|c|}{$\begin{array}{l}\text { Chicks and growers } \\
\text { (week 1-7) }\end{array}$} & \multicolumn{3}{|c|}{$\begin{array}{l}\text { Growers and pullets } \\
\quad \text { (week 8-16) }\end{array}$} & \multicolumn{3}{|c|}{$\begin{array}{l}\text { Laying hens } \\
\text { (week 17-41) }\end{array}$} \\
\hline & LA & AA & HA & LA & AA & HA & LA & AA & HA \\
\hline Barley & 200.0 & 200.0 & 200.0 & 300.0 & 300.0 & 300.0 & 240.2 & 240.2 & 240.2 \\
\hline Wheat & 100.0 & 100.0 & 100.0 & 150.0 & 150.0 & 150.0 & - & - & - \\
\hline Triticale & - & - & - & 147.5 & 147.5 & 147.5 & - & - & - \\
\hline Corn & 399.0 & 396.0 & 386.0 & 209.5 & 208.5 & 201.5 & 553.8 & 551.5 & 544.5 \\
\hline Corn gluten meal & 150.0 & 150.0 & 150.0 & 80.0 & 80.0 & 80.0 & 68.8 & 68.8 & 68.8 \\
\hline Lucerne pellets & 50.0 & 50.0 & 50.0 & 60.0 & 60.0 & 60.0 & - & - & - \\
\hline Wheat bran & 39.8 & 39.8 & 39.8 & - & - & - & - & - & - \\
\hline Soybean oil & 10.0 & 10.0 & 10.0 & 10.0 & 10.0 & 10.0 & 10.0 & 10.0 & 10.0 \\
\hline Calcium carbonate & - & - & - & 7.0 & 7.0 & 7.0 & 85.2 & 85.2 & 85.2 \\
\hline Calcium phosphate & 33.3 & 33.3 & 33.3 & 20.0 & 20.0 & 20.0 & 16.3 & 16.3 & 16.3 \\
\hline Premix $^{1}$ & 10.0 & 10.0 & 10.0 & - & - & - & - & - & - \\
\hline Premix $^{2}$ & - & - & - & 10.0 & 10.0 & 10.0 & - & - & - \\
\hline Premix $^{3}$ & - & - & - & - & - & - & 10.0 & 10.0 & 10.0 \\
\hline L-lysine $\mathrm{HCl}$ & 4.9 & 4.9 & 4.9 & 2.6 & 2.6 & 2.6 & 6.3 & 6.3 & 6.3 \\
\hline L-arginine & - & 3.0 & 13.0 & - & 1.0 & 8.0 & - & 2.3 & 9.3 \\
\hline Sodium chloride & 3.0 & 3.0 & 3.0 & 3.4 & 3.4 & 3.4 & 2.6 & 2.6 & 2.6 \\
\hline DL-methionine & - & - & - & - & - & - & 1.7 & 1.7 & 1.7 \\
\hline L-threonine & - & - & - & - & - & - & 0.2 & 0.2 & 0.2 \\
\hline L-tryptophan & - & - & - & - & - & - & 0.7 & 0.7 & 0.7 \\
\hline L-valine & - & - & - & - & - & - & 1.8 & 1.8 & 1.8 \\
\hline L-isoleucine & - & - & - & - & - & - & 2.4 & 2.4 & 2.4 \\
\hline \multicolumn{10}{|c|}{ chemical composition, $\mathrm{g} / \mathrm{kg}$ diet } \\
\hline Dry matter ${ }^{4}$ & 897.6 & 893.0 & 896.6 & 888.4 & 891.4 & 891.7 & 895.4 & 897.1 & 896.3 \\
\hline Crude ash $^{4}$ & 60.0 & 57.2 & 58.2 & 52.1 & 53.2 & 54.2 & 119.3 & 117.1 & 119.7 \\
\hline Crude protein ${ }^{4}$ & 174.1 & 176.0 & 186.9 & 128.1 & 132.5 & 136.2 & 119.4 & 121.6 & 128.5 \\
\hline Kjeldahl Nitrogen ${ }^{4}$ & 27.9 & 28.5 & 32.0 & 20.5 & 21.9 & 23.1 & 19.1 & 19.8 & 22.0 \\
\hline Crude fat $^{4}$ & 40.1 & 38.6 & 37.2 & 30.7 & 31.6 & 34.6 & 40.2 & 41.1 & 40.6 \\
\hline Crude fiber ${ }^{4}$ & 33.6 & 31.0 & 34.2 & 38.5 & 39.3 & 39.3 & 20.9 & 22.7 & 22.5 \\
\hline $\operatorname{Starch}^{4}$ & 459.7 & 457.7 & 449.5 & 493.2 & 491.8 & 482.8 & 492.8 & 492.1 & 462.7 \\
\hline Sucrose $^{4}$ & 20.6 & 20.1 & 20.3 & 23.8 & 24.3 & 23.0 & 20.5 & 20.8 & 20.6 \\
\hline Phosphorous ${ }^{4}$ & 9.8 & 10.0 & 10.2 & 13.9 & 14.3 & 13.8 & 5.2 & 5.6 & 5.8 \\
\hline Calcium $^{4}$ & 12.7 & 12.6 & 13.1 & 11.5 & 11.8 & 11.6 & 40.9 & 41.0 & 40.3 \\
\hline $\operatorname{AME}_{N}(M J / k g)^{5}$ & 12.0 & 12.0 & 12.0 & 11.6 & 11.6 & 11.6 & 11.7 & 11.7 & 11.7 \\
\hline Methionine $^{6}$ & 3.34 & 3.34 & 3.32 & 2.43 & 2.43 & 2.42 & 3.90 & 3.90 & 3.89 \\
\hline Lysine $^{6}$ & 8.96 & 8.96 & 8.93 & 6.26 & 6.26 & 6.24 & 9.14 & 9.13 & 9.12 \\
\hline Arginine $^{6}$ & 6.54 & 9.53 & 19.50 & 5.45 & 6.46 & 13.44 & 4.47 & 6.76 & 13.74 \\
\hline \multicolumn{10}{|c|}{$\begin{array}{l}{ }^{1} \text { Premix - chicks: feed additives (per kg premix): Vitamin A, 1,200,000 IU; Vitamin } \mathrm{D}_{3}, 350,000 \mathrm{IU} \text {; Vitamin E, 4,000 mg; Vitamin } \mathrm{B}_{1}, 250 \mathrm{mg} \text {; } \\
\text { Vitamin } \mathrm{B}_{2}, 800 \mathrm{mg} \text {; Vitamin } \mathrm{B}_{6}, 600 \mathrm{mg} \text {; Vitamin } \mathrm{B}_{12}, 3,200 \mu \mathrm{g} \text {; Vitamin } \mathrm{K}_{3}, 450 \mathrm{mg} \text {; Nicotin amide, 4,500 mg; Calcium-D-pantothenate, } \\
1,500 \mathrm{mg} \text {; Folic acid, } 120 \mathrm{mg} \text {; Biotin, 5,000 } \mathrm{gg} \text {; Choline chloride, } 55,000 \mathrm{mg} ; \mathrm{Fe}, 3,200 \mathrm{mg} \text {; Cu, 1,200 mg; Mn, 10,000 mg; Zn, 8,000 mg; } \text {, } \\
160 \mathrm{mg} \text {; Se, } 40 \mathrm{mg} \text {; Co, } 20 \mathrm{mg} \text {; Butylated hydroxy toluene (BHT), } 10,000 \mathrm{mg}\end{array}$} \\
\hline \multicolumn{10}{|c|}{$\begin{array}{l}{ }^{2} \text { Premix - pullets: feed additives (per kg premix): Vitamin A, 1,000,000 IU; Vitamin } \mathrm{D}_{3}, 200,000 \mathrm{IU} \text {; Vitamin E, 2,500 mg; Vitamin } \mathrm{B}_{1}, 250 \mathrm{mg} \text {; } \\
\text { Vitamin } \mathrm{B}_{2}, 500 \mathrm{mg} \text {; Vitamin } \mathrm{B}_{6}, 400 \mathrm{mg} \text {; Vitamin } \mathrm{B}_{12}, 1,850 \mu \mathrm{g} \text {; Vitamin } \mathrm{K}_{3}, 300 \mathrm{mg} \text {; Nicotin amide, } 3.000 \mathrm{mg} \text {; Calcium-D-pantothenate, } 900 \\
\mathrm{mg} \text {; Folic acid, } 80 \mathrm{mg} \text {; Biotin, 2,100 } \mathrm{g} \text {; Choline chloride, } 30,000 \mathrm{mg} ; \mathrm{Fe}, 4,000 \mathrm{mg} \text {; Cu, 1,500 mg; Mn, 8,000 mg; Zn, 8,000 mg; I, } 160 \mathrm{mg} \text {; Se, } \\
32 \mathrm{mg} \text {; Co, } 20 \mathrm{mg} \text {; Butylated hydroxy toluene (BHT), } 10,000 \mathrm{mg}\end{array}$} \\
\hline \multirow{2}{*}{\multicolumn{10}{|c|}{$\begin{array}{l}{ }^{3} \text { Premix - hens: feed additives (per kg premix): Vitamin A, 1,000,000 IU; Vitamin } \mathrm{D}_{3}, 250,000 \mathrm{IU} \text {; Vitamin E, 2,000 mg; Vitamin } \mathrm{B}_{1}, 250 \mathrm{mg} \text {; } \\
\text { Vitamin } \mathrm{B}_{2}, 700 \mathrm{mg} \text {; Vitamin } \mathrm{B}_{6}, 400 \mathrm{mg} \text {; Vitamin } \mathrm{B}_{12}, 2,000 \mu \mathrm{g} ; \text { Vitamin } \mathrm{K}_{3}, 400 \mathrm{mg} \text {; Nicotin amide, 4,000 mg; Calcium-D-pantothenate, } \\
1,000 \mathrm{mg} \text {; Folic acid, } 60 \mathrm{mg} \text {; Biotin, 2,500 } \mu \mathrm{g} \text {; Choline chloride, 40,000 mg; Fe, 4,000 mg; Cu, 1,000 mg; Mn, 10,000 mg; Zn, } 8,000 \mathrm{mg} ; \mathrm{I}, 120 \\
\text { mg; Se, } 25 \mathrm{mg} \text {; Co, } 20.5 \mathrm{mg} \text {; Butylated hydroxy toluene (BHT), 12,500 mg; Beta-carotene, } 400 \mathrm{mg} \text {; Canthaxanthin, } 400 \mathrm{mg}\end{array}$}} \\
\hline & & & & & & & & & \\
\hline $\begin{array}{l}{ }^{5} \text { Apparent metaboli } \\
\text { equation of the } \mathrm{WI}\end{array}$ & $\begin{array}{l}\text { gy concer } \\
1986)\end{array}$ & tions cor & d to zer & trogen $b$ & ce $(\mathrm{AMF}$ & calculate & cording & he energ & stimation \\
\hline
\end{tabular}


half an hour per week to 14 hours of light at $23^{\text {rd }}$ week of age. After a pre-laying period from week 17 to 21 with continuous data recording, the performance trial comprised five 28-day laying periods and lasted from week 22 to 41 .

Laying hens were weighed at the end of each 28-day laying period. The number of laid eggs was recorded daily. For each laying period egg weight (EW) was monitored by collecting all laid eggs of each pen on four consecutive days in a two-week interval. Residual feed was recorded weekly. Based on recorded data daily feed intake (DFI), laying intensity (LI), daily egg mass (DEM) and the feed to egg mass ratio (FEM) were calculated.

\section{Egg Quality Parameters}

At the end of each laying period $\left(25^{\text {th }}, 29^{\text {th }}, 33^{\text {rd }}, 37^{\text {th }}\right.$ and $41^{\text {th }}$ week of age) all laid eggs were collected on four consecutive days ( $25^{\text {th }}$ week: 665 eggs, $29^{\text {th }}$ week: 790 eggs, $33^{\text {rd }}$ week: 640 eggs, $39^{\text {th }}$ week: 580 eggs and $41^{\text {st }}$ week: 430 eggs). Eggs were weighed and egg yolk and albumen were separated. Weight of shell, including inner shell membrane, and weight of yolk were recorded. Weight of albumen was determined by subtracting yolk and shell weight from the original egg weight. Egg components were presented in percentage as proportions of the total egg weight. Yolk colour (YC) was estimated by using a Roche-fan (15 fans, F. Hoffmann-La Roche Ltd., Basel, Switzerland).

As protein and amino acid deposition in eggs were considered to be genetically determined and virtually insensitive to dietary manipulations (Roland, 1980a, b; Leeson, 1993; Hussein and Harms, 1994), we assume that the Arg concentration in egg yolk (11.36 $\mathrm{mg} \mathrm{Arg} / \mathrm{g}$ ) and egg albumen (5.92 $\mathrm{mg} \mathrm{Arg} / \mathrm{g}$ ) described by Bergquist (1979) were applicable to our examined eggs. Therefore, daily Arg transfer into total egg and its components yolk and albumen were calculated by multiplying daily egg mass by the proportion of egg yolk or albumen and the corresponding Arg concentration described by Bergquist (1979). Dividing daily Arg transfer into egg by daily Arg intake, the partial Arg utilization for egg production was determined.

\section{Dry Matter and Crude Nutrients of Feed}

Diets (Table 1) were analysed for dry matter, crude ash, crude fat, crude fibre, starch, sucrose, phosphorous, calcium and Kjeldahl $\mathrm{N}$ according to the methods of the Association of German Agricultural Analytic and Research Institutes (VDLUFA; Bassler, 1993). Dietary crude protein of the basal diets was calculated by multiplying Kjeldahl $\mathrm{N}$ by 6.25 . As nitrogen content of Arg is twice as high as that of crude protein the nitrogen differences between Arg supplemented diets and the basal diet were multiplied by 3.13 in order to avoid an overestimation of dietary crude protein in the supplemented diets. The apparent metabolisable energy concentration corrected to zero nitrogen balance $\left(\mathrm{AME}_{\mathrm{N}}\right)$ of diets was calculated according to the energy estimation equation of the World's Poultry Science Association (Vogt, 1986). In order to calculate the concentrations of amino acids in the experimental diets appropriately, amino acid containing feed components others than those supplemented in their free forms were analyzed for their containing amounts of amino acids by ion exchange chromatography according to the description of analytical methods in AMINODat ${ }^{\circledR} 4.0$ (Evonik Industries, 2010).

\section{Modelling of Growth Curves}

The growth function of Gompertz (1825) was fitted regressively to time-dependent individually recorded growth data (cumulative growth; $n=36$ per group) from hatch to the end of the $41^{\text {st }}$ week of age using procedure "nonlinear regression" of the software package "Statistica 12.0 for the Windows ${ }^{\mathrm{TM}}$ Operating System" (Statsoft Inc., 2014). The equation parameters were estimated using the iterative Quasi-Newton method.

$$
y(t)=a \cdot e^{-b \cdot e^{-c \cdot t}}
$$

Where $y(t)=$ body weight $(g)$ of the hen at time $t$, expressed as a function of $\mathrm{a}$; $\mathrm{a}=$ adult body weight $(\mathrm{g})$ of the hen (asymptotic limit); b,c $=$ parameters of the function (regression coefficients); and $\mathrm{t}=$ time (weeks). The age at maximum body weight gain $\left(t_{\max }\right)$ that is equivalent to the point of inflection of the cumulative, sigmoid growth curve was calculated by the second derivative of the cumulative growth function:

$$
t_{\max }=\frac{\ln b}{c}
$$

The maximum daily weight gain was computed by applying the group specific calculated $t_{\max }$ in the derivative of the cumulative growth function for the corresponding experimental group.

\section{Statistical Analyses}

Statistical analysis of performance traits, egg quality parameters and the partial Arg utilization was carried out by means of a three factorial analysis of variance (ANOVA) with genotype, diet and age as well as their interactions as fixed effects. For traits measured repeatedly on the same animal a "repeated" statement was considered in the statistical model to account for similarities within subjects. For calculated growth function parameters, a two factorial ANOVA with genotype and diet as well as their interaction as fixed effects was carried out. In both cases the TukeyKramer test was applied for a multiple comparison of means. Data were reported as least square means and pooled standard errors. Differences were considered to be statistically significant for $P<0.05$. The ANOVA were performed using the procedure MIXED of the software package SAS 9.4 (SAS Institute Inc., 2012).

\section{Results}

\section{Rearing Trial}

Growth development and rearing performance are presented in Table 2. BW was significantly affected by GT, diet and age as well as their two-factorial interactions. At hatch BW did not differ between GTs, but it increased timedependently and GTs differed from week 4 onwards $(p<$ $0.001)$. Brown GTs achieved a higher BW than white ones $(p<0.001)$, and L68 and WLA reached the highest BW within phenotypes. During the entire trial R11 showed the 
Table 2. Effect of Arg supply and genotype on growth performance from hatch to the $16^{\text {th }}$ week of age

\begin{tabular}{|c|c|c|c|c|c|c|c|c|c|c|c|c|c|c|c|c|c|c|}
\hline \multicolumn{3}{|c|}{ WLA } & \multicolumn{3}{|c|}{ BLA } & \multicolumn{3}{|c|}{$\mathrm{R} 11$} & \multicolumn{3}{|c|}{ L68 } & \multicolumn{7}{|c|}{ ANOVA ( $\mathrm{p}$ values) } \\
\hline LA & AA & HA & LA & AA & HA & LA & AA & HA & LA & AA & HA & 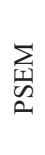 & ט & 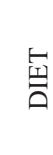 & 罗 & 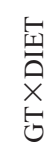 & 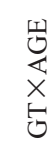 & 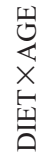 \\
\hline
\end{tabular}

\begin{tabular}{|c|c|c|c|c|c|c|c|c|c|c|c|c|c|c|c|c|c|c|c|}
\hline \multicolumn{20}{|c|}{ Body weight, $\mathrm{g} /$ chick } \\
\hline hatch & 38 & 39 & 38 & 39 & 37 & 38 & 33 & 34 & 33 & 42 & 43 & 40 & 5 & \multirow{5}{*}{$\begin{array}{l}\overrightarrow{8} \\
\dot{0} \\
\vee\end{array}$} & \multirow{5}{*}{$\begin{array}{l}\overline{8} \\
\dot{0} \\
\dot{v}\end{array}$} & \multirow{5}{*}{$\begin{array}{l}\overline{8} \\
\dot{0} \\
\vee\end{array}$} & \multirow{5}{*}{$\begin{array}{l}\ddot{0} \\
\dot{\circ}\end{array}$} & \multirow{5}{*}{$\begin{array}{l}\overline{8} \\
\dot{0}\end{array}$} & \multirow{5}{*}{$\begin{array}{l}\overline{8} \\
\dot{0} \\
\vee\end{array}$} \\
\hline week 4 & $190^{\mathrm{b}}$ & $217^{\mathrm{a}}$ & $207^{\mathrm{ab}}$ & $194^{\mathrm{b}}$ & $216^{\mathrm{a}}$ & $222^{\mathrm{a}}$ & $168^{\mathrm{c}}$ & $194^{\mathrm{b}}$ & $186^{\mathrm{bc}}$ & $209^{\mathrm{ab}}$ & $227^{\mathrm{a}}$ & $207^{\mathrm{ab}}$ & 5 & & & & & & \\
\hline week 8 & $439^{\mathrm{de}}$ & $511^{\mathrm{c}}$ & $509^{\mathrm{c}}$ & $454^{\mathrm{d}}$ & $519^{\mathrm{c}}$ & $527^{\mathrm{bc}}$ & $361^{\mathrm{f}}$ & $429^{\text {de }}$ & $418^{\mathrm{e}}$ & $505^{\mathrm{c}}$ & $598^{\mathrm{a}}$ & $560^{\mathrm{b}}$ & 6 & & & & & & \\
\hline week 12 & $756^{\mathrm{g}}$ & $850^{\mathrm{de}}$ & $832^{\mathrm{e}}$ & $793^{f}$ & $867^{\mathrm{d}}$ & $869^{\mathrm{d}}$ & $620^{\mathrm{i}}$ & $718^{\mathrm{h}}$ & $693^{\mathrm{h}}$ & $904^{\mathrm{c}}$ & $1016^{\mathrm{a}}$ & $973^{\mathrm{b}}$ & 8 & & & & & & \\
\hline week 16 & $1064^{\mathrm{g}}$ & $1158^{\mathrm{e}}$ & $1134^{\mathrm{ef}}$ & $1114^{\mathrm{f}}$ & $1184^{\mathrm{de}}$ & $1210^{\mathrm{d}}$ & $934^{\mathrm{i}}$ & $1027^{\mathrm{gh}}$ & $1000^{\mathrm{h}}$ & $1270^{\mathrm{c}}$ & $1400^{\mathrm{a}}$ & $1362^{\mathrm{b}}$ & 10 & & & & & & \\
\hline \multicolumn{20}{|c|}{ Daily weight gain, g/chick/d } \\
\hline week $1-4$ & $5.4^{\mathrm{b}}$ & $6.4^{\mathrm{a}}$ & $6.0^{\mathrm{ab}}$ & $5.5^{\mathrm{ab}}$ & $6.4^{\mathrm{a}}$ & $6.6^{\mathrm{a}}$ & $4.8^{\mathrm{b}}$ & $5.7^{\mathrm{ab}}$ & $5.5^{\mathrm{ab}}$ & $6.0^{\mathrm{ab}}$ & $6.6^{\mathrm{a}}$ & $6.0^{\mathrm{ab}}$ & 0.4 & \multirow{4}{*}{$\begin{array}{l}\overline{8} \\
\dot{0} \\
\vee\end{array}$} & \multirow{4}{*}{\multicolumn{2}{|c|}{$\begin{array}{ll}\overline{8} & \overline{8} \\
\dot{0} & \dot{0} \\
\vee & v\end{array}$}} & \multirow{4}{*}{$\dot{\leftrightarrow}$} & \multirow{4}{*}{$\begin{array}{l}\overline{8} \\
\dot{0} \\
\vee\end{array}$} & \multirow{4}{*}{$\begin{array}{l}\overline{8} \\
\overline{0} \\
\vee\end{array}$} \\
\hline week $5-8$ & $8.9^{\mathrm{c}}$ & $10.5^{\mathrm{b}}$ & $10.8^{\mathrm{b}}$ & $9.3^{\mathrm{c}}$ & $10.8^{\mathrm{b}}$ & $10.9^{\mathrm{b}}$ & $6.9^{\mathrm{d}}$ & $8.4^{\mathrm{c}}$ & $8.3^{\mathrm{c}}$ & $10.6^{\mathrm{b}}$ & $13.3^{\mathrm{a}}$ & $12.6^{\mathrm{a}}$ & 0.4 & & & & & & \\
\hline week 9-12 & $11.3^{\mathrm{c}}$ & $12.1^{\mathrm{bc}}$ & $11.5^{\mathrm{bc}}$ & $12.1^{\mathrm{bc}}$ & $12.4^{\mathrm{b}}$ & $12.2^{\mathrm{b}}$ & $9.3^{\mathrm{e}}$ & $10.3^{\mathrm{d}}$ & $9.8^{\mathrm{de}}$ & $14.3^{\mathrm{a}}$ & $14.9^{\mathrm{a}}$ & $14.8^{\mathrm{a}}$ & 0.4 & & & & & & \\
\hline week $13-16$ & $11.0^{\mathrm{c}}$ & $11.0^{\mathrm{c}}$ & $10.8^{\mathrm{c}}$ & $11.5^{\mathrm{c}}$ & $11.3^{\mathrm{c}}$ & $12.2^{\mathrm{bc}}$ & $11.2^{\mathrm{c}}$ & $11.0^{\mathrm{c}}$ & $11.0^{\mathrm{c}}$ & $13.1^{\mathrm{ab}}$ & $13.7^{\mathrm{a}}$ & $13.9^{\mathrm{a}}$ & 0.5 & & & & & & \\
\hline \multicolumn{20}{|c|}{ Daily feed intake, $\mathrm{g} / \mathrm{chick} / \mathrm{d}$} \\
\hline week $1-4$ & $15.7^{\mathrm{b}}$ & $17.3^{\mathrm{b}}$ & $17.7^{\mathrm{ab}}$ & $18.4^{\mathrm{ab}}$ & $15.9^{\mathrm{b}}$ & $15.4^{\mathrm{b}}$ & $19.4^{\mathrm{a}}$ & $17.5^{\mathrm{b}}$ & $18.5^{\mathrm{ab}}$ & $20.4^{\mathrm{a}}$ & $18.7^{\mathrm{ab}}$ & $20.7^{\mathrm{a}}$ & 1.1 & \multirow{4}{*}{$\begin{array}{l}\overline{8} \\
\dot{0} \\
\dot{V}\end{array}$} & \multirow{4}{*}{\multicolumn{2}{|c|}{$\begin{array}{ll}\bar{\delta} & \overline{8} \\
\dot{0} & \dot{0} \\
\vee & \vee\end{array}$}} & \multirow{4}{*}{$\begin{array}{l}\stackrel{2}{o} \\
\stackrel{0}{v}\end{array}$} & \multirow{4}{*}{$\begin{array}{l}\overline{8} \\
\dot{0} \\
\vee\end{array}$} & \multirow{4}{*}{$\begin{array}{l}\overline{8} \\
\dot{0} \\
\vee\end{array}$} \\
\hline week 5-8 & $34.2^{\mathrm{c}}$ & $38.3^{\mathrm{b}}$ & $38.0^{\mathrm{b}}$ & $34.2^{\mathrm{c}}$ & $38.1^{\mathrm{b}}$ & $38.0^{\mathrm{b}}$ & $30.8^{\mathrm{d}}$ & $33.1^{\mathrm{c}}$ & $33.6^{\mathrm{c}}$ & $37.0^{\mathrm{b}}$ & $43.1^{\mathrm{a}}$ & $43.1^{\mathrm{a}}$ & 1.1 & & & & & & \\
\hline week 9-12 & $54.3^{\mathrm{c}}$ & $55.6^{\mathrm{c}}$ & $56.3^{\mathrm{c}}$ & $55.0^{\mathrm{c}}$ & $56.2^{\mathrm{c}}$ & $55.6^{\mathrm{c}}$ & $49.9^{\mathrm{d}}$ & $51.3^{\mathrm{d}}$ & $49.4^{\mathrm{d}}$ & $60.1^{\mathrm{b}}$ & $66.3^{\mathrm{a}}$ & $64.3^{\mathrm{ab}}$ & 1.1 & & & & & & \\
\hline week $13-16$ & $66.3^{\mathrm{d}}$ & $69.3^{\mathrm{c}}$ & $68.0^{\mathrm{cd}}$ & $65.1^{\mathrm{de}}$ & $64.2^{\mathrm{de}}$ & $65.0^{\mathrm{de}}$ & $59.8^{\mathrm{e}}$ & $62.5^{\mathrm{e}}$ & $61.5^{\mathrm{e}}$ & $74.6^{\mathrm{b}}$ & $77.7^{\mathrm{a}}$ & $75.2^{\mathrm{ab}}$ & 1.2 & & & & & & \\
\hline \multicolumn{20}{|c|}{ Feed conversion ratio, $\mathrm{g} / \mathrm{g}$} \\
\hline week 1-4 & $2.9^{\mathrm{bc}}$ & $2.7^{\mathrm{bc}}$ & $2.9^{\mathrm{bc}}$ & $3.3^{\mathrm{ab}}$ & $2.5^{\mathrm{bc}}$ & $2.3^{\mathrm{bc}}$ & $4.0^{\mathrm{a}}$ & $3.1^{\mathrm{b}}$ & $3.4^{\mathrm{ab}}$ & $3.4^{\mathrm{ab}}$ & $2.8^{\mathrm{bc}}$ & $3.4^{\mathrm{ab}}$ & 0.3 & \multirow{5}{*}{$\begin{array}{l}\overrightarrow{0} \\
\dot{0} \\
\vee\end{array}$} & \multirow{5}{*}{$\stackrel{\dot{\varphi}}{=}$} & & \multirow{5}{*}{$\stackrel{\dot{\leftrightarrow}}{\dot{g}}$} & \multirow{5}{*}{$\begin{array}{l}\overrightarrow{8} \\
\dot{0} \\
\vee\end{array}$} & \multirow{5}{*}{$\stackrel{\dot{g}}{=}$} \\
\hline week 5-8 & $3.8^{\mathrm{ab}}$ & $3.6^{\mathrm{ab}}$ & $3.5^{\mathrm{ab}}$ & $3.7^{\mathrm{ab}}$ & $3.5^{\mathrm{ab}}$ & $3.5^{\mathrm{ab}}$ & $4.5^{\mathrm{a}}$ & $3.9^{\mathrm{ab}}$ & $4.1^{\mathrm{ab}}$ & $3.5^{\mathrm{ab}}$ & $3.2^{\mathrm{b}}$ & $3.4^{\mathrm{b}}$ & 0.3 & & & & & & \\
\hline week 9-12 & $4.8^{\mathrm{ab}}$ & $4.6^{\mathrm{ab}}$ & $4.9^{\mathrm{ab}}$ & $4.5^{\mathrm{b}}$ & $4.5^{\mathrm{b}}$ & $4.6^{\mathrm{ab}}$ & $5.4^{\mathrm{a}}$ & $5.0^{\mathrm{ab}}$ & $5.0^{\mathrm{ab}}$ & $4.2^{\mathrm{b}}$ & $4.4^{\mathrm{b}}$ & $4.3^{\mathrm{b}}$ & 0.3 & & & 8 & & & \\
\hline week $13-16$ & $6.0^{\mathrm{ab}}$ & $6.3^{\mathrm{a}}$ & $6.3^{\mathrm{a}}$ & $5.7^{\mathrm{ab}}$ & $5.7^{\mathrm{ab}}$ & $5.3^{\mathrm{b}}$ & $5.3^{\mathrm{b}}$ & $5.7^{\mathrm{ab}}$ & $5.6^{\mathrm{ab}}$ & $5.7^{\mathrm{ab}}$ & $5.7^{\mathrm{ab}}$ & $5.4^{\mathrm{b}}$ & 0.3 & & & & & & \\
\hline week $1-16$ & 4.4 & 4.3 & 4.4 & 4.3 & 4.0 & 3.9 & 4.8 & 4.4 & 4.5 & 4.2 & 4.0 & 4.1 & 0.4 & & & & & & \\
\hline
\end{tabular}

${ }^{\mathrm{a}-\mathrm{i}}$ LSMeans values with PSEM $(n=50$ chicks/experimental group) in the same row with different superscripts are significantly different $(p<0.05)$ n.s. $=$ not significant

lowest BW, whereas HPGTs differed between each other in week 16 only. From week 4 onwards the insufficient Arg diet caused the lowest BW in all GTs, but the highest BW was recorded in chicks fed with $\mathrm{AA}$ and HA $(p<0.001)$, equally. LA and HA caused differences between GTs as described above $(p<0.001)$, but AA induced no differences between WLA and BLA. Differences between supplemented diets occurred in L68 only, as AA caused higher BW than HA $(p<0.001)$.

DWG was influenced by GT, diet and age as well as the interactions GT $x$ age and diet $x$ age $(p<0.001)$. From week 5 onwards DWG differed between GTs for the first time, and R11 gained the lowest and L68 the highest BW daily $(p<$ 0.001). However, HPGTs gained BW to the same extent during the entire rearing period. From week 9 to 12 all GTs but R11 reached their highest DWG and they decreased afterwards $(p<0.001)$. R11 achieved its highest DWG in the last four weeks of rearing. At the end of trial L68 differed from the other GTs only. The Arg deficit group had the lowest DWG among all GTs $(p<0.001)$.

DFI was significantly affected by GT, diet and age as well as their two-factorial interactions. Although DFI increased age-dependently $(p<0.001)$, HPGTs did not differ during rearing. Independent of diet L68 had the highest and R11 the lowest DFI from week 5 onwards $(p<0.001)$. In contrast to the deficit diet, AA caused higher DFI among all GTs from week 5 to 8 and in L68 from week 9 to 16 as well $(p<0.01)$.

FCR was only affected by GT, age and their interaction $(p<0.01)$. A dietary influence on FCR did not occur. The lowest FCR was performed during the first 4 weeks of rearing, in which HPGTs significantly differed from LPGTs. Afterwards FCR increased age-dependently ( $p<0.001)$, and GTs did not differ anymore. In general, the cumulative FCR of the entire rearing did not differ between GTs and diets.

During rearing an average mortality of $1.22 \%$ was recorded. Although $90 \%$ of losses occurred during the first five weeks of age, specific influences were not found.

Adaptation of the Gompertz, Function to the Growth Data

The Gompertz function was fitted to growth data by nonlinear regression. The results are summarized in Table 3 and graphically presented in Figs. $1 \mathrm{a}-\mathrm{b}$ and $1 \mathrm{e}^{-\mathrm{f}}$. The calculated parameters of the group-specific growth functions, $\mathrm{t}_{\max }$, and its corresponding maximum DWG were significantly affected by GT and diet. The asymptotic limit of 
Table 3. Effect of Arg supply and genotype on results of time-dependent individual growth data fitted to the Gompertz function $^{1}$

\begin{tabular}{|c|c|c|c|c|c|c|c|c|c|c|c|c|c|c|c|c|}
\hline & \multicolumn{3}{|c|}{ WLA } & \multicolumn{3}{|c|}{ BLA } & \multicolumn{3}{|c|}{ R11 } & \multicolumn{3}{|c|}{ L68 } & \multicolumn{4}{|c|}{ ANOVA ( $\mathrm{p}$ values) } \\
\hline & LA & AA & HA & LA & AA & HA & LA & AA & HA & LA & AA & HA & PSEM & GT & DIET & $\begin{array}{l}\text { GT } \times \\
\text { DIET }\end{array}$ \\
\hline a (g/chick) & $1503^{d}$ & $1492^{\mathrm{d}}$ & $1537^{\mathrm{d}}$ & $1756^{\mathrm{c}}$ & $1770^{\mathrm{bc}}$ & $1819^{b}$ & $1342^{\mathrm{e}}$ & $1422^{\mathrm{e}}$ & $1404^{\mathrm{e}}$ & $1887^{\mathrm{b}}$ & $1964^{\mathrm{ab}}$ & $1977^{\mathrm{a}}$ & 29 & $<0.001$ & $<0.05$ & n.s. \\
\hline $\mathrm{b}$ & $3.67^{\mathrm{bc}}$ & $3.66^{\mathrm{bc}}$ & $3.61^{\mathrm{c}}$ & $3.85^{\mathrm{a}}$ & $3.58^{\mathrm{c}}$ & $3.57^{\mathrm{c}}$ & $3.74^{\mathrm{b}}$ & $3.65^{\mathrm{bc}}$ & $3.63^{\mathrm{bc}}$ & $3.78^{\mathrm{ab}}$ & $3.74^{\mathrm{b}}$ & $3.91^{\mathrm{a}}$ & 0.04 & $<0.001$ & $<0.01$ & $<0.001$ \\
\hline $\mathrm{c}$ & $0.140^{\mathrm{c}}$ & $0.157^{\mathrm{a}}$ & $0.147^{\mathrm{b}}$ & $0.133^{\mathrm{d}}$ & $0.136^{\mathrm{cd}}$ & $0.133^{\mathrm{d}}$ & $0.135^{\mathrm{cd}}$ & $0.142^{\mathrm{bc}}$ & $0.138^{\mathrm{c}}$ & 0.135 & $0.143^{\mathrm{bc}}$ & $0.142^{\mathrm{bc}}$ & 0.002 & $<0.001$ & $<0.001$ & n.s. \\
\hline$t_{\max }$ (weeks) & $9.36^{\mathrm{bc}}$ & $8.33^{\mathrm{d}}$ & $8.76^{\mathrm{cd}}$ & $10.22^{\mathrm{a}}$ & $9.44^{\mathrm{bc}}$ & $9.65^{\mathrm{b}}$ & $9.82^{\mathrm{ab}}$ & $9.17^{\mathrm{c}}$ & $9.35^{\mathrm{bc}}$ & $9.94^{\mathrm{ab}}$ & $9.30^{\mathrm{bc}}$ & $9.60^{\mathrm{bc}}$ & 0.16 & $<0.001$ & $<0.001$ & n.s. \\
\hline $\mathrm{R}^{2}$ & 0.998 & 0.998 & 0.998 & 0.997 & 0.998 & 0.997 & 0.998 & 0.998 & 0.998 & 0.998 & 0.998 & 0.998 & & & & \\
\hline RSD & 24 & 22 & 20 & 25 & 26 & 22 & 22 & 20 & 19 & 26 & 24 & 30 & & & & \\
\hline Estimated & & & & & & & & & & & & & & & & \\
\hline $\begin{array}{l}\text { MDWG } \\
\text { (g/chick/d) }\end{array}$ & $11.1^{\mathrm{e}}$ & $12.3^{\mathrm{cd}}$ & $11.9^{\mathrm{d}}$ & $12.3^{\mathrm{cd}}$ & $12.6^{\mathrm{c}}$ & $12.7^{\mathrm{c}}$ & $9.5^{\mathrm{g}}$ & $10.6^{\mathrm{ef}}$ & $10.2^{\mathrm{f}}$ & $13.4^{\mathrm{b}}$ & $14.8^{\mathrm{a}}$ & $14.7^{\mathrm{a}}$ & 0.2 & $<0.001$ & $<0.001$ & $<0.01$ \\
\hline $\begin{array}{l}\text { Achieved } \\
\text { MDWG } \\
\text { (g/chick/d) }\end{array}$ & $11.0^{\mathrm{e}}$ & $12.1^{\mathrm{d}}$ & $12.1^{\mathrm{d}}$ & $12.9^{\mathrm{c}}$ & $12.7^{\mathrm{cd}}$ & $13.2^{\mathrm{c}}$ & $9.5^{\mathrm{f}}$ & $11.0^{\mathrm{e}}$ & $10.0^{\mathrm{f}}$ & $14.6^{\mathrm{b}}$ & $15.5^{\mathrm{a}}$ & $15.0^{\mathrm{ab}}$ & 0.3 & $<0.001$ & $<0.001$ & n.s. \\
\hline
\end{tabular}

${ }^{\mathrm{a}-\mathrm{g}}$ LSMeans values with PSEM ( $n=36$ chicks/experimental group) in the same row with different superscripts are significantly different $(p<$ $0.05)$

1: $y(t)=a \cdot e^{-b \cdot e^{-c \cdot t}}$ with $\mathrm{y}=$ body weight at time $\mathrm{t}$ and the regression coefficients a (asymptotic limit=adult body weight), $\mathrm{b}$ and $\mathrm{c}$ $t_{\max }$ : equivalent to the point of inflection (time of maximum weight gain)

$\mathrm{R}^{2}=$ coefficient of determination; $\mathrm{RSD}=$ residual standard deviation; PSEM=pooled standard error of mean; MDWG $=$ maximum daily weight gain

n.s. $=$ not significant

growth curves, equal to estimated adult $\mathrm{BW}$, was lower in white GTs compared with brown ones $(p<0.001)$. In addition, HA fed brown GTs showed higher asymptotic BW than those of the deficit group $(p<0.01)$. On the other hand, AA fed WLA reached $t_{\max }$ at first, and LA fed BLA grew slowest $(p<0.05)$. Independent of diet, $\mathrm{t}_{\max }$ of WLA differed significantly from those of the other GTs that showed no difference between each other. However, AA caused fastest growth among all GTs and differed significantly from LA and HA, equally.

Figs. $1 \mathrm{c}-\mathrm{d}$ and $1 \mathrm{~g}-\mathrm{h}$ present the derivatives of growth curves, identical to the course of DWG. The graphs show a significant DWG increase until group-specific $t_{\max }$ with its corresponding estimated maximum DWG. Brown GTs achieved higher maximum DWG than white GTs $(p<0.001)$. However, the marginal Arg groups induced significantly lower maximum DWG at $t_{\max }$ among all GTs. Consequently, curves of deficit groups were flatter than those of AA and HA $(p<0.001)$. After reaching its maximum, DWG decreased strongly and approached nearly zero-gain asymptotically after the $40^{\text {th }}$ week of age.

\section{Growth, Feed Intake and Laying Performance}

Table 4 summarizes growth development and laying performance of GTs from week 22 to 41 . Hens' BW was significantly affected by GT, diet and age as well as their interactions. Independent of diet and age, brown hens achieved higher BW than white ones $(p<0.001)$, and L68 and WLA showed highest BW within phenotypes. BW of GTs except L68 increased until week $25(p<0.001)$, whereas L68 gained BW until week 33 and remained constant afterwards like R11 $(p<0.001)$. On the other hand,
HPGTs lost weight continuously and differed from each other during the entire laying period $(p<0.001)$. Although R11 received the lowest BW among all GTs $(p<0.001)$, white GTs did not differ between each other after week 29. R11 was not affected by diet, but AA and HA fed R11 achieved higher BW compared to WLA from week 34 to 41 . In general, the deficit Arg group had the lowest $\mathrm{BW}(p<$ 0.001), but HPGTs showed no difference between each other until week 29. In contrast to AA and HA, LA fed WLA reached higher $\mathrm{BW}$ from week 30 to 41, whereas AA and HA induced higher BW in L68 until week 33 and until week 41 in BLA $(p<0.001)$.

Furthermore, DFI was influenced by GT, diet and age as well as the interactions of GT $\mathrm{x}$ diet, GT $\mathrm{x}$ age and GT $\mathrm{x}$ diet $\mathrm{x}$ age $(p<0.001)$. In general, brown hens consumed more feed than white ones $(p<0.001)$, and BLA and R11 showed highest DFI within their phylogenetic groups. All GTs dropped their DFI continuously after its maximum in week 29 (HPGTs) or in week 33 (LPGTs; $p<0.001$ ). Until week 25 WLA consumed more feed than R11, but this condition became reversed until the end of trial. DFI of all GTs except R11 was affected by the diets $(p<0.001)$, because increasing amounts of dietary Arg induced DFI decrease in BLA and DFI increase in L68. Consequently, LA caused a higher DFI in BLA than in L68, and AA and HA were more fed by L68 than by BLA $(p<0.001)$. Additionally, WLA consumed more AA than HA $(p<0.01)$.

Moreover, high performing WLA (week 21) and BLA (week 22) reached the onset of laying, defined by the first egg laid, at first. L68 averagely started to lay in the $23^{\text {rd }}$ week of age and R11 two weeks later. Due to the different 


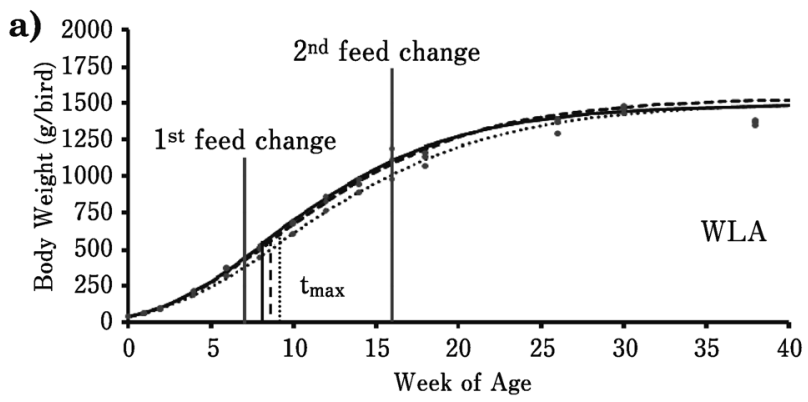

c)

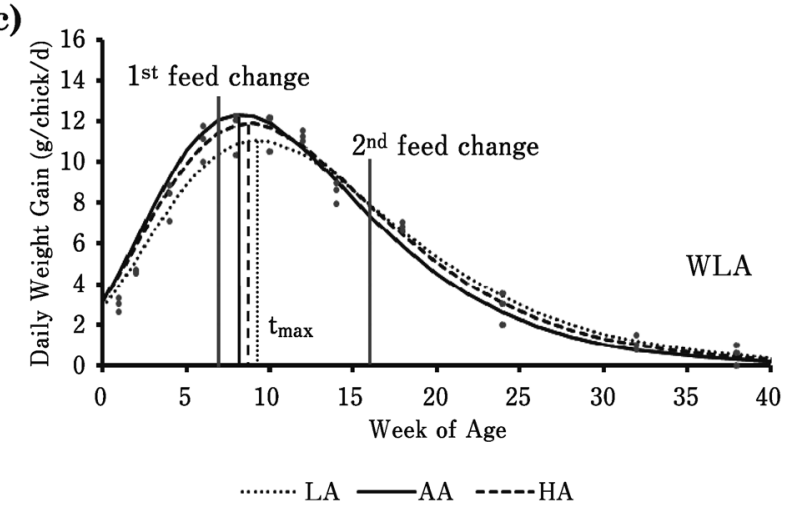

e)

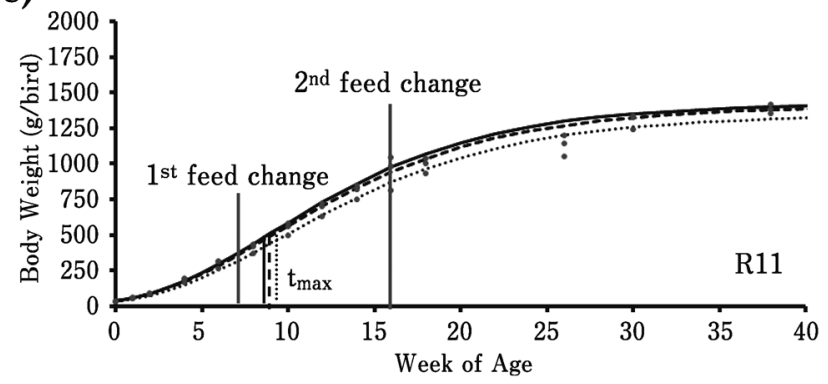

g)

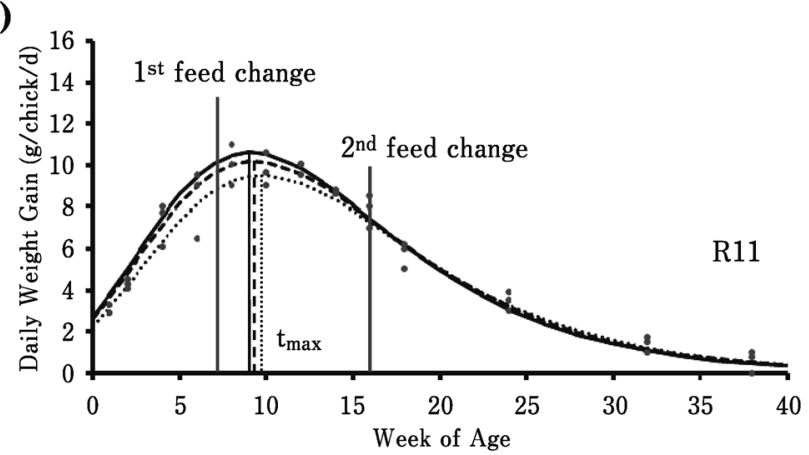

.......... LA

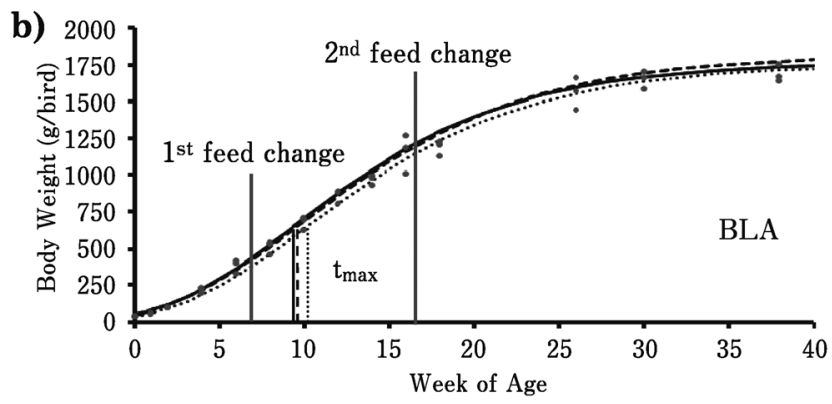

d)

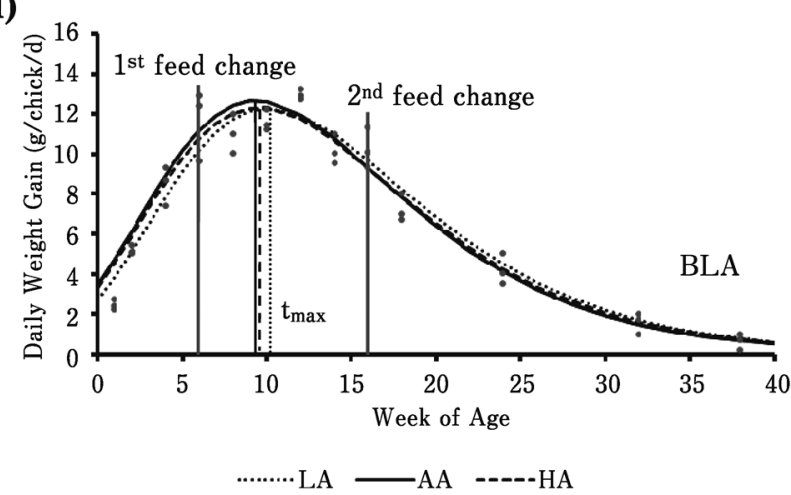

f)

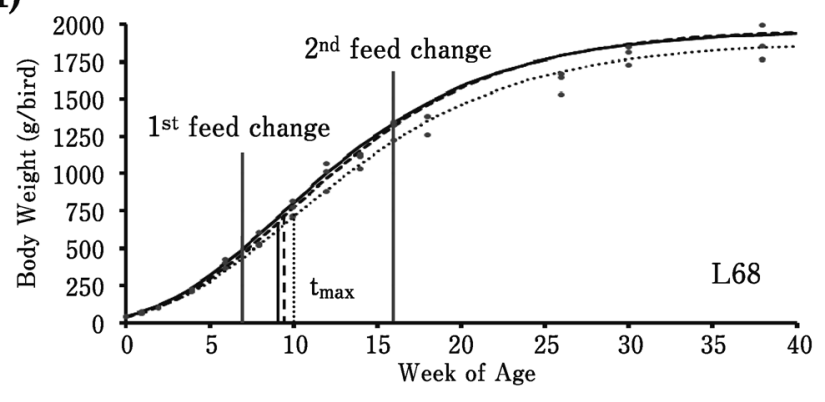

h)

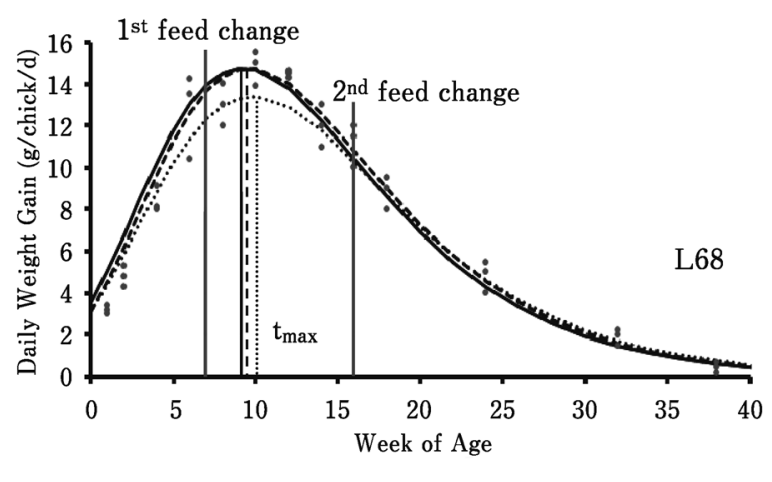

......... LA

${ }^{1} y(t)=a \cdot e^{-b \cdot e^{-c \cdot t}}$ with $\mathrm{y}=$ body weight at time $\mathrm{t}$ and the regression coefficients a (asymptotic limit $=$ adult body weight), $\mathrm{b}$ and $\mathrm{c}$

Fig. 1. Graphic presentation of non-linear regression of genotypes' growth data depending on L-arginine supply from hatch to week 41 fitted to the Gompertz equation ${ }^{1}\left(a-b\right.$ and $\left.e^{-} f\right)$ and derived course of daily weight gain $\left(c^{-} d\right.$ and $\left.g^{-h}\right)$ with emphasis of the genotype specific $\mathrm{t}_{\max }(n=36)$. 
Table 4. Effect of Arg supply and genotype on growth and laying performance from the 22nd to 41st week of age

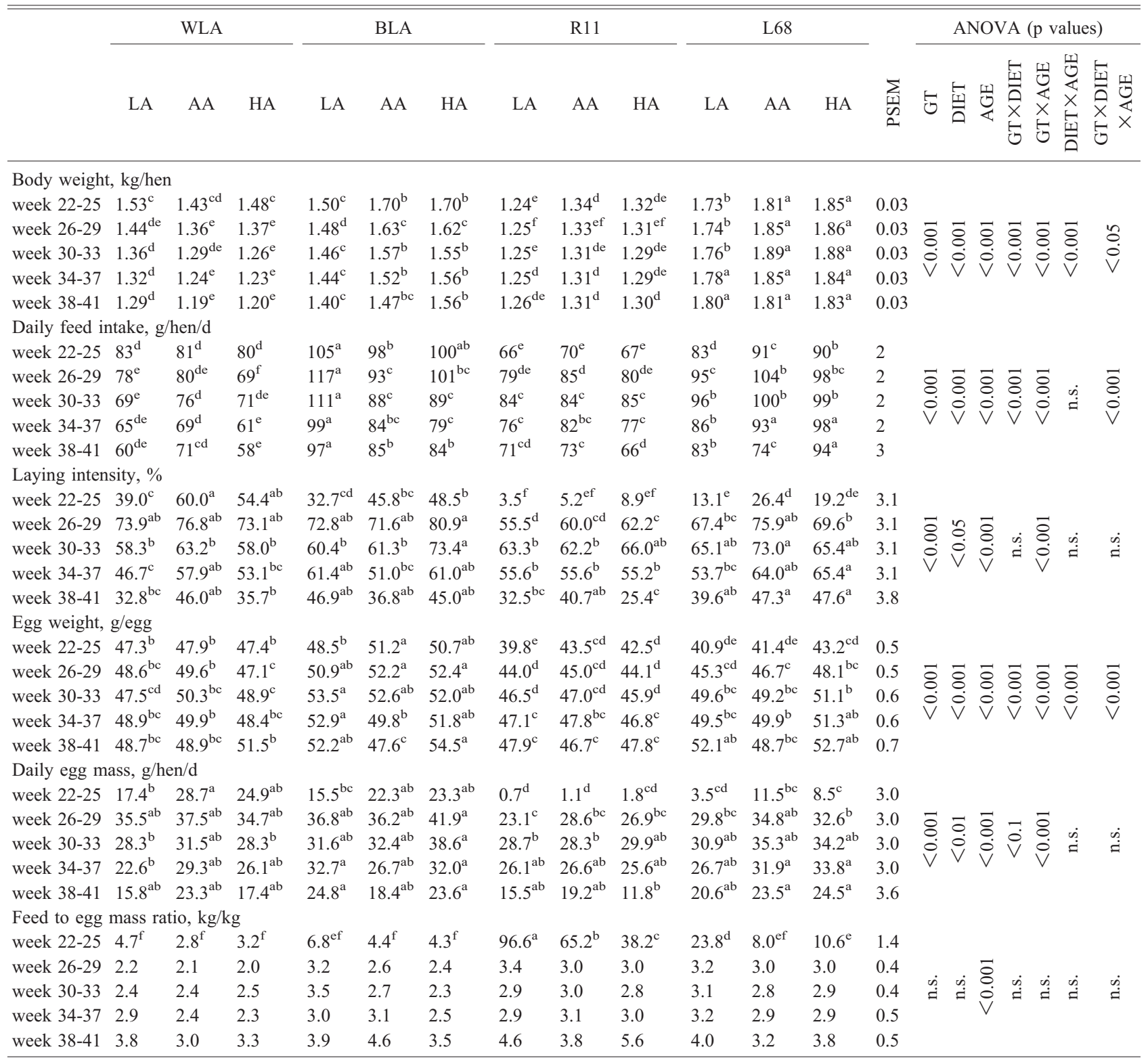

${ }^{\mathrm{a}-\mathrm{f}}$ LSMeans values with PSEM $(n=36$ chicks/experimental group) in the same row with different superscripts are significantly different $(p<0.05)$ n.s. $=$ not significant

age at onset of laying, laying intensity (LI), daily egg mass (DEM) and feed to egg mass ratio (FEM) showed large differences between and within GTs in the first four weeks of trial.

LI was significantly affected by GT, diet and age as well as the interaction of GT $x$ age. During the entire trial, the LI did not differ between HPGTs, whereas LPGTs differed significantly between each other and from HPGTs until week 25 ( $p<0.001)$. From week 26 to 29 GTs except R11 achieved their maximum LI and decreased strongly afterwards $(p<0.001)$. However, R11 reached its maximum four weeks later and their LI decreased strongly in the following, too. After week 30 HPGTs decreased so strong in LI that they even undercut the LI of L68 $(p<0.01)$. In the following, GTs except L68 did not differ between each other anymore. In general, the deficit groups showed lower LI than AA and HA $(p<0.05)$, occasionally.

Total EW was influenced by GT, diet and age as well as their interactions $(p<0.001)$. Brown eggs were heavier than white ones $(p<0.001)$, and HPGTs laid heavier eggs than LPGTs until week $33(p<0.001)$. From week 29 onwards L68 and R11 differed from each other $(p<0.001)$. All GTs except BLA showed an EW increase until week $41(p<$ $0.001)$, whereas EW of BLA increased until week 33 and 
Table 5. Effect of Arg supply and genotype on egg quality of eggs ${ }^{1}$ examined at the end of each laying month

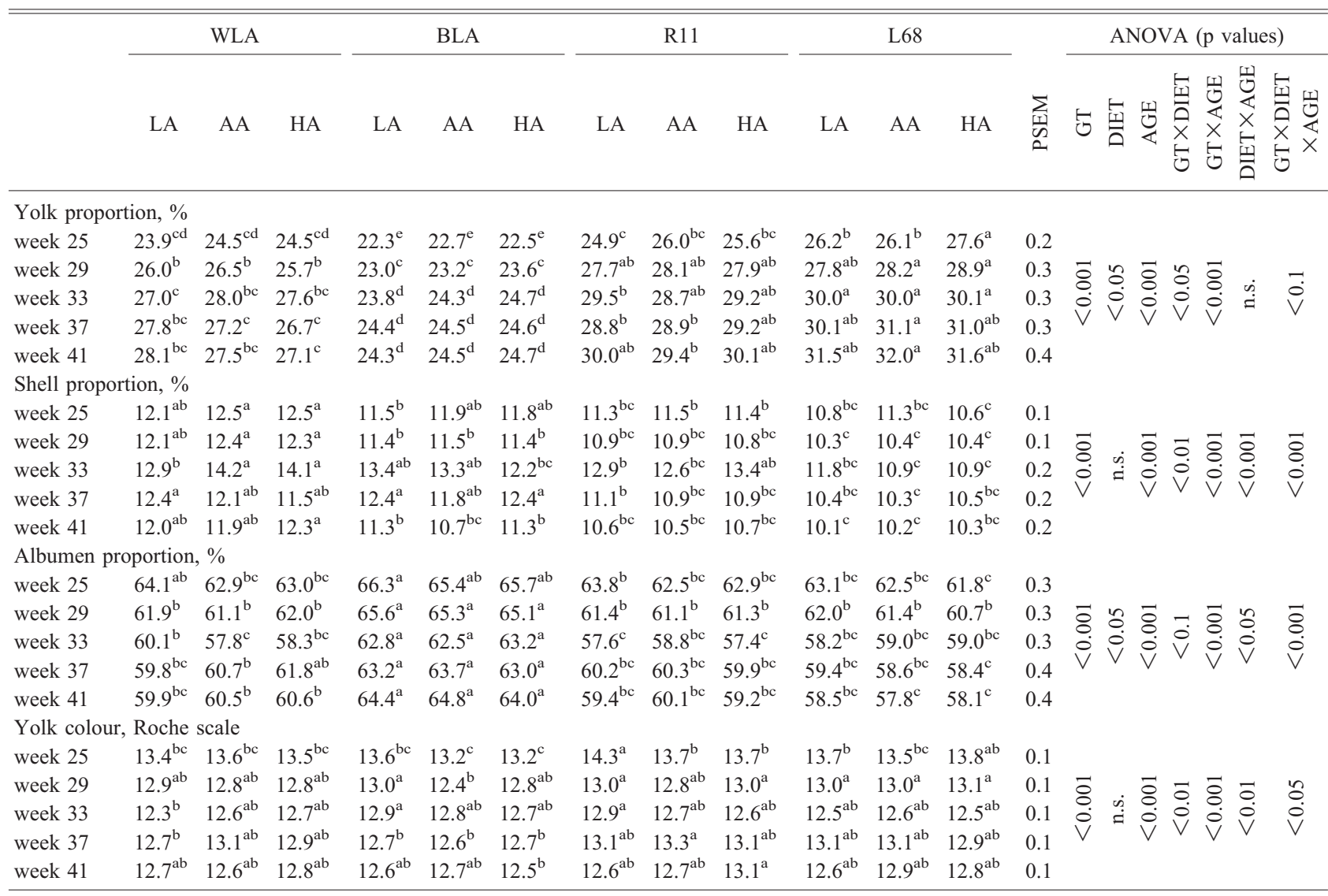

${ }^{1}$ : eggs collected on four consecutive days of $n=36$ hens of each experimental group

Proportions of egg components are calculated as weight of components (yolk, shell and albumen) per weight of total egg.

${ }^{\mathrm{a}-\mathrm{d}}$ LSMeans values with PSEM $(n=36$ chicks/experimental group) in the same row with different superscripts are significantly different $(p<0.05)$ n.s. $=$ not significant

decreased afterwards. Until week 29 AA fed WLA and L68 differed from each other $(p<0.001)$, but they received same weights onwards. L68's EW was statistically not affected by diet. In contrast to LA and HA, AA caused higher EW in WLA in week 29, in BLA in the weeks 25 and 37, and in R11 in week $25(p<0.001)$.

The calculated DEM was affected by GT, diet and age as well as the interaction of GT $\mathrm{x}$ age $(p<0.01)$. BLA achieved the highest DEM and differed from LPGTs $(p<0.001)$. WLA and L68 had higher DEM than R11 $(p<0.001)$. In general, the deficit group caused the lowest DEM among all GTs $(p<0.01)$. In week 26 to 29 HPGTs achieved their maximum DEM and they decreased strongly until the end of trial $(p<0.001)$. However, LPGTs reached their maximum four weeks later and decreased afterwards $(p<0.001)$, too.

FEM was only affected by hens' age $(p<0.001)$. Due to later onset of laying, LPGTs showed extremely high FEM and differed from HPGTs in the first four weeks of trial $(p<$ $0.01)$. FEM decreased rapidly from week 26 to 33 and restarted to increase until the end of trial $(p<0.001)$.

During the entire trial a mortality of $4.2 \%$ was recorded.
Losses of each GT are listed in the following ascending order: R11 0.0\% - WLA 4.6\% - BLA 5.6\% and L68 6.5\%.

\section{Egg Quality}

Table 5 presents the results of the egg quality examination. Yolk proportion of examined eggs was significantly affected by GT, diet and age as well as the interactions GT $\mathrm{x}$ diet and GT $x$ age. Eggs of HPGTs contained a lower yolk proportion than eggs of LPGTs $(p<0.001)$. The latter ones did not differ from each other, whereas WLA showed a higher yolk proportion than BLA. During the entire trial L68 eggs increased in yolk proportion $(p<0.05)$, but those of the other GTs enlarged their yolk proportion only until week 33 and remained constant afterwards $(p<0.001)$. In contrast to the insufficient Arg diet, HA caused higher yolk proportion in L68 in week $25(p<0.05)$.

Egg shell proportion was influenced by GT and age as well as by the interaction of GT $\mathrm{x}$ diet, GT $\mathrm{x}$ age and GT $\mathrm{x}$ diet $\mathrm{x}$ age $(p<0.001)$. In contrast to LPGTs, HPGTs showed higher shell proportion $(p<0.001)$, and white hens laid eggs with higher shell proportion than brown hens. Until week 33 all GTs but L68 increased in shell proportion and they 
decreased onwards $(p<0.001)$. However, L68 had a constant shell proportion. Egg shell proportion was not affected by diet in all GTs but WLA, whose shell proportion was elevated by AA and HA in week $33(p<0.05)$.

Proportion of albumen was significantly influenced by GT, diet and age as well as GT $\mathrm{x}$ age, diet $\mathrm{x}$ age and GT $\mathrm{x}$ diet $\mathrm{x}$ age. HPGTs laid eggs with higher albumen proportion compared with LPGTs $(p<0.001)$. BLA achieved highest albumen proportion and L68 showed the lowest proportion ( $p$ $<0.001$ ), but white GTs did not differ from each other. Until week 33 all GTs but L68 showed a decrease, and a consecutive slight re-increase up to week $41 \quad(p<0.001)$. However, L68's albumen proportion decreased continuously to the end of trial. A dietary impact on albumen proportion was only found in WLA, as AA caused a higher proportion than LA in week $33(p<0.05)$.

YC was significantly influenced by GT and age as well as by two- and three-factorial interactions. LPGTs had more intense coloured yolks than HPGTs $(p<0.001)$. YC was not solely affected by diet, but it changed age-dependently $(p<$ 0.001). The intensity of YC decreased until week 33 and slightly re-increased until week 41.

In order to estimate the partial Arg utilization for egg production, the absolute daily Arg transfer into the egg and its protein containing proportions was calculated at first. These transfer parameters (data not shown) differed significantly between GTs, diets and age in the way DEM and the egg proportions did, because these parameters were the mathematical product of the constant Arg concentrations described by Bergquist (1979), the DEM and the relative weight of the corresponding egg component. The further calculated partial Arg utilization for egg synthesis (Fig. 2) was affected by GT, diet and age $(p<0.001)$. The highest partial Arg utilization for the total egg and those for egg yolk and albumen was found in WLA $(p<0.001)$. BLA showed a higher partial Arg utilization for egg albumen than LPGTs ( $p$ $<0.01$ ), whereas L68 achieved a higher partial Arg utilization for egg yolk compared to BLA and R11. If dietary Arg supply elevated from LA to HA, the partial Arg utilization of all egg components decreased strongly $(p<0.001)$. The partial Arg utilization for egg albumen and that for total egg reached their maximum from week 26 to 29 , and that for egg yolk peaked four weeks later $(p<0.001)$.

\section{Discussion}

With regard to Rauw et al. (1998), van der Waaij (2004) and Mirkena et al. (2010), we hypothesized that selection for high production efficiency in layers caused highly adapted HPGTs, which were less capable to cope with environmental stress compared to LPGTs. Since studied GTs were considered to be well suited for the established animal model concerning the required phylogenetic (Granevitze et al., 2009; Lyimo et al., 2014) and performance divergence (Lieboldt et al., 2015), the present study was conducted to examine interactions between these GTs and long-term graded Arg supply serving as nutritional-environmental stress on growth development and performance of diverse purebred layer lines.

During the entire trial GTs were fed with diets equivalent to 70,100 and $200 \%$ Arg of recommended level (NRC, 1994). Long-term effects of graded Arg supply from rearing to laying were of great importance, because significant differences in BW, DWG and DFI occurred between and within GTs at the end of rearing. These Arg-induced differences might cause diverse initial conditions for hens at the beginning of laying that could serve as carry-over effect from rearing to laying.

In the last years poultry research directed its attention frequently to the strong effects of dietary Arg on chicken's performance (Kwak et al., 1999, 2001; Chamruspollert et al., 2004; Jahanian, 2009; Bulbul et al., 2013; Wang et al., 2014a). Comparable responses to graded dietary Arg supply were found in studied GTs, because insufficient dietary Arg induced significant growth reduction and retardation compared to an adequate or surplus Arg supply during rearing. The estimated parameters of the Gompertz equation also indicated that adequate or even surplus dietary Arg might induce higher adult $\mathrm{BW}$ than insufficient Arg. In addition, lowest maximum DWG and highest $t_{\max }$ were determined for chicks fed with insufficient Arg diets. Such generally growth-retarding and genetically independent effects could be explained by the adverse effects of dietary imbalances between Arg and Lys (D'Mello and Lewis, 1970; D'Mello and Lewis, 1971; Jahanian, 2009) and Arg and Met (Keshavarz and Fuller, 1971a, b). Additionally, a dietary insufficient Arg supply lowered the plasma concentrations of Arg and ornithine directly and induced a lack of these metabolizable amino acids (Kwak et al., 1999 and 2001). Austic and Calvert (1981), D'Mello (1994) and Keshavarz and Fuller (1971a) described the subsequently disturbed metabolic pathways of polyamine and creatine formation, which form the basis for growth retardation and reduction in poultry suffering from insufficient and imbalanced dietary Arg. As a consequence, the Arg requirement elevated and induced a secondary growth depression (D'Mello, 1994).

Furthermore, L68 showed its strongest growth with an adequate Arg supply, whereas both White Leghorn lines and BLA developed with adequate and surplus Arg equally. Possible explanations were given by the genetically determined differences in Arg utilization and metabolism. The different rapidity in feathering caused a higher Arg requirement in fast feathering GTs during early life stage (Hegstedt et al., 1941). For L68, a lower Arg requirement could be assumed in times of feather development, because L68 was intentionally selected for slow feathering (K 30\%, k $70 \%$ ). The growth retardation in Arg oversupplied L68 might be explained by the enhanced endogenous Arg:Lys antagonism (Nesheim, 1968; Kwak et al., 2001, Balnave and Brake, 2002), and revealed a higher sensitivity of L68 for high Arg:Lys ratios. On the other hand, WLA seemed to belong to those fast feathering GTs with higher Arg requirement, because it grew well and fast with adequate and oversupplied Arg, equally.

Moreover, insufficient Arg induced a strong reduction of 

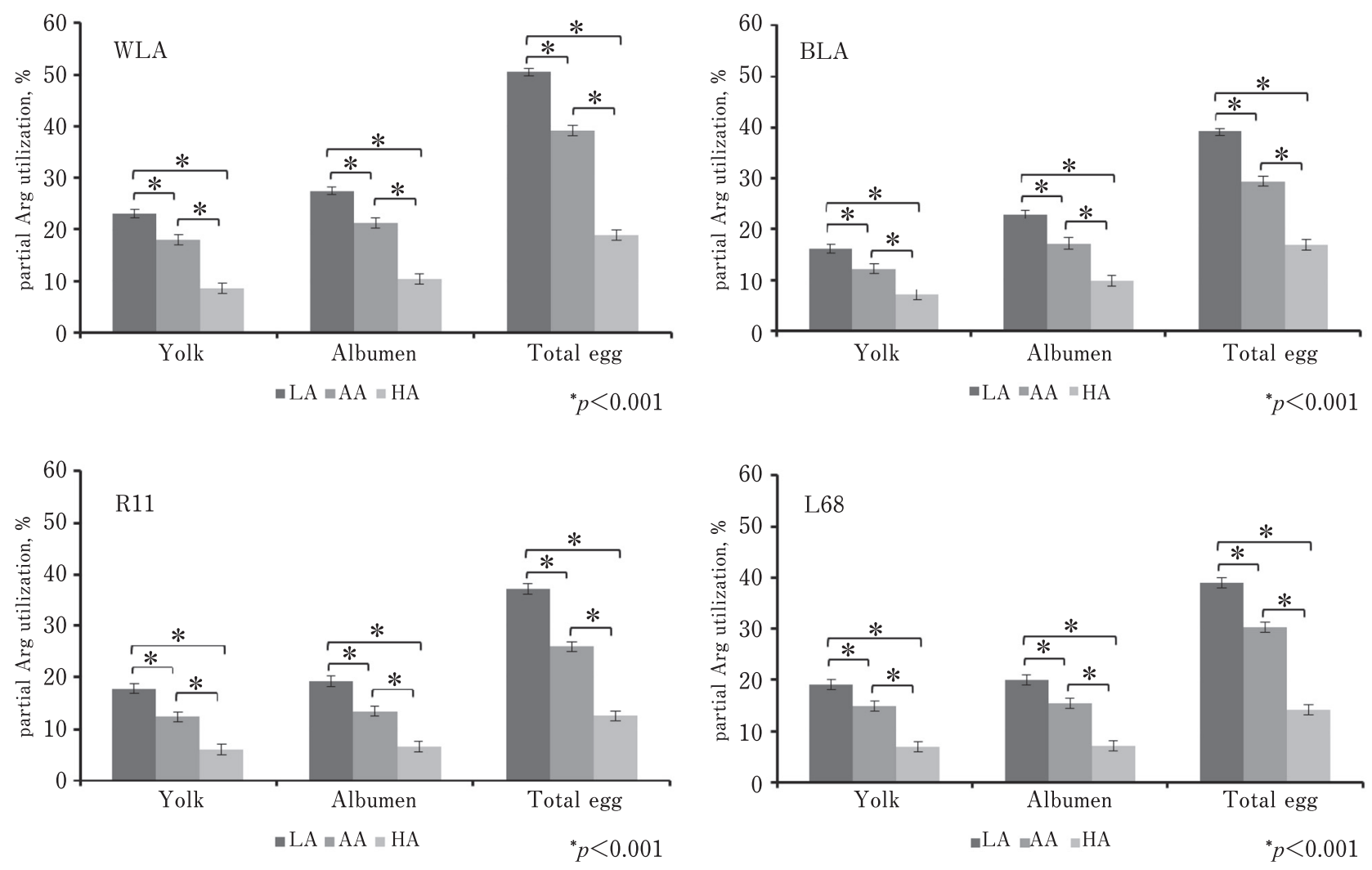

Fig. 2. Graphic presentation of calculated partial utilization of dietary Arg for egg synthesis during performance trial (LSMeans $\pm \mathrm{SE}$; $n=36$ ).

feed intake in studied GTs during rearing. This effect was most evident in WLA and L68, whereas BLA and R11 responded only from week 5 to 8 . Harper et al. (1970) reported on anorectic effects of dietary amino acid imbalances and D'Mello and Lewis (1971) described the Arg: Lys antagonism that caused avian growth depression and induced appetite reduction, secondary. However, mechanisms of appetite inhibition caused by insufficient dietary Arg were intensively examined by Wang et al. $(2014 \mathrm{a}, \mathrm{b})$ in White Pekin ducks. The authors concluded that appetite inhibition might be a consequence of hypothalamic changes in protein expression and NO involved mechanisms of appetite regulation hormones. Based on the present study we could not consider with certainty if growth reduction has been a secondary effect of reduced feed intake induced by hypothalamic biochemical changes or resulted from adverse effects of limited metabolizable Arg in growth metabolism.

In general, our study confirmed the importance of Arg for growth-promotion during the rearing period and showed comparable results to the most studies dealing with dietary Arg in poultry (Chamruspollert et al., 2004; Jahaninan, 2009; Bulbul et al., 2013; Wang et al., 2014a, b). However, these studies were carried out in growing meat-type poultry such as broilers and ducks, and recent reports on dietary effects of Arg in laying hens were not existent to the best of our knowledge. In contrast to the rearing period, the corresponding GTs responded very different to the diets during the laying period. We assumed that the carry-over effect from rearing to laying and the dietary concentration of crude protein were responsible for the varying results between the GTs and diets. Whereas chicks, growers and pullets were fed with sufficient concentrations of crude protein (NRC, 1994), the calculated basal diet for hens contained a relatively low concentration of crude protein in order to generate an Arg insufficient diet for laying hens. Roland (1980a and 1980b) emphasized the negative effects of low dietary crude protein on laying performance and egg quality. On reaching final adult BW studied GTs maintained their BW and DFI constant under commercial feeding conditions (Lieboldt et al., 2015). In the present study the LPGTs reached this plateau phase after the $29^{\text {th }}$ week of age, whereas the HPGTs showed a strong decrease in BW after the $25^{\text {th }}$ week of age. That strong decrease in BW was paralleled by a similarly directed decrease in DFI and laying performance, which were adversely affected by increasing amounts of dietary Arg. The mobilisation of body mass and its associated reduction of laying performance expressed the metabolic stress HPGTs suffering from under the given plan of nutrition. In parti- 
cular the carry-over effect from rearing to laying, the dietary limitation in crude protein (Chi and Speers, 1976; Roland, 1980a, b) and the early onset of laying were main factors of metabolic stress in HPGTs. However, the dietary amino acids imbalances described by D'Mello and Lewis (1970) and Keshavarz and Fuller (1971a) seemed to play a minor role, especially in the HPGTs, because the actual effects of graded Arg supply might be masked by the stronger factors named before. The effects of dietary Arg supply on laying hens were most obvious in LPGTs, because BW, DFI and laying performance of R11 was not affected by diet and those of L68 even responded to insufficient Arg in the same way like reared L68. That led to the assumption that differences found in LPGT hens were stronger influenced by the different grades of dietary Arg as by the relatively low dietary crude protein. Because present LPGT hens showed a comparable performance to those under commercial feeding conditions (Lieboldt et al., 2015), the required dietary crude protein was nearly met by the formulated hen diets in order to achieve their genetically determined performance potential.

Although egg yolk contained physiologically higher amounts of Arg than egg albumen (Bergquist, 1979), our examination of egg quality did not indicate that insufficient Arg or crude protein supply caused lower proportions of yolk and higher ones of albumen. Roland (1980a, b), Leeson (1993), and Hussein and Harms (1994) reported on the virtual insensitivity of protein and amino acid deposition to dietary manipulation in eggs and meat and emphasized the genetic determination of these egg nutrients. The present study confirmed that the yolk protein synthesis was not selectively restricted by an insufficient Arg or crude protein supply. Studied laying hens responded to the adverse dietary effects by a general reduction of total egg weight and occasional shifts in egg proportions in order to reduce the loss of required amino acids into the egg. However, the amount of calculated daily transferred Arg into egg showed no differences between offered diets. The calculated partial Arg utilization for egg production reflected the intended graduation of dietary Arg, because the highest Arg utilization occurred in the insufficiently supplied hens. On reaching maximum Arg transfer into egg, a further Arg supplementation was not benefit for the synthesis of egg proteins. Consequently, the Arg not used for the synthesis of egg proteins in adequate and oversupplied diets became available for other metabolic pathways in hen's body. Perhaps those large amounts of metabolizable Arg might also exacerbate the endogenous Arg:Lys antagonism and enhanced the adverse effects on BW and performance of laying hens as described above.

Finally, Mirkena et al. (2010) classified the ability of reducing metabolism and performance in order to allocate not used nutrients to fitness associated traits like a stable BW as an advantage in times of poor feed quality. If GTs were unable to respond in this way, Beilharz et al. (1993) and Rauw et al. (1998) rated that inability as undesirable sideeffect of selection on high production efficiency. If more nutrients were required for production related traits, they were taken away from fitness and allocated to production traits. Consequently, metabolic stress accompanied with decreased health, fertility and energy available for maintenance would occur with negative effects on reproduction and probability of survival (van der Waaji, 2004). The established animal model of the present study seemed to be well suited for approaching that theory from an experimental point of view. The current results suggested that selection on high production efficiency caused HPGTs that were less able to cope with insufficient nutritional conditions in contrast to LPGTs.

In conclusion, growth and feed intake depressive properties of insufficient dietary Arg have been clearly shown in growing birds. The nutritional-environmental stress induced by strong limitations of Arg and crude protein in laying hens revealed HPGTs inability of simultaneous performance reduction and BW maintenance. Therefore, further and more detailed studies should be carried out in order to examine the metabolic and even immunological response of GTs to dietary limitations.

\section{Acknowledgment}

The authors gratefully acknowledge Karsten Knop and his staff for the care of the experimental animals, the sample and data collection and practical realization of experiments as well as Annerose Junghans for her participation at sample preparation.

\section{References}

Austic RE and Calvert CC. Nutritional interrelationships of electrolytes and amino acids. Federation Proceedings, 40: 63-67. 1981.

Balnave D and Brake J. Re-evaluation of the classical dietary arginine:lysine interaction for modern poultry diets: a review. World's Poultry Science Journal, 58: 275-289. 2002.

Bassler R. VDLUFA-Methodenbuch. Die chemische Untersuchung von Futtermitteln. Loose leaflet collection with supplements from 1983, 1988, 1993, and 1997. Vol.3. VDLUFA-Verlag. Darmstadt. 1997.

Beilharz RG, Luxford BG and Wilkinson JL. Quantitative genetics and evolution: Is our understanding of genetics sufficient to explain evolution? Journal of Animal Breeding and Genetics, 110: 161-170. 1993.

Bequette BJ. Amino acid metabolism in animals, In: Amino Acids in Animal Nutrition (D’Mello JPF ed.). Vol. 2. pp. 87-101. CABI Publishing. Wallingford. 2003.

Bergquist. In: Geflügel (Scholtyssek S ed.). p.38. Eugen Ulmer Verlag Stuttgart. 1987.

Block RJ. The composition of keratins: The amino acid composition of hair, wool, horn and other eukeratins. Journal of Biological Chemistry, 128: 181-186. 1939.

Brake J, Balnave D and Dibner JJ. Optimum dietary arginine: lysine ratio for broiler chickens is altered during heat stress in association with changes in intestinal uptake and sodium chloride. British Poultry Science, 39: 639-647. 1998.

Bulbul T, Bozkurt Z, Ulutas E, Yilmaz O and Bulbul A. The Effect of L-Arginine on Growth Performance, Some Serum Biochemical Parameters and Duodenal Motility in Broilers. Kafkas Universitesi Veteriner Fakultesi Dergisi, 19: 821-827. 2013. 
Burton EM and Waldroup PW. Arginine and lysine needs of young broiler chicks. Nutrition Report International, 19: 607-614. 1979.

Chamruspollert G, Pesti GM and Bakalli RI. Influence of temperature on the arginine and methionine requirements of young broiler chicks. Journal of Applied Poultry Research, 13: 628638. 2004.

Chi MS and Speers GM. Effects of Dietary Protein and Lysine Levels on Plasma Amino Acids, Nitrogen Retention and Egg Production in Laying Hens. Journal of Nutrition, 106: 11921201. 1976.

Cuca M and Jensen LS. Arginine requirement of starting broiler chicks. Poultry Science, 69: 1377-1382. 1990.

D'Mello JPF and Lewis D. Amino acid interactions in chick nutrition. 1. The interrelationship between lysine and arginine. British Poultry Science, 11: 299-311. 1970.

D'Mello JPF and Lewis D. Amino acid interactions in chick nutrition. 4. Growth, food intake and plasma amino acid patterns. British Poultry Science, 12: 345-358. 1971.

D’Mello JPF. Amino acid imbalances, antagonisms and toxicities. In: Amino Acids in Farm Animal Nutrition (D’Mello JPF ed.). Vol. 1. pp. 63-97. CABI Publishing. Wallingford. 1994.

Evonik Industries. Analystical Methods. In: AMINODat ${ }^{\circledR} 4.050$ years amino acid analysis (Redshaw MS, Flicker J, Fontaine J, Heimbeck W, and Hess V eds). pp. 8-18. Evonik Degussa GmbH, Hanau. 2010.

Farr SA, Banks WA, Kumar VB and Morely JE. Orexin-A-induced feeding is dependent on nitric oxide. Peptides, 26: 759-765. 2005.

Gaskin FS, Farr SA, Banks WA, Kumar VB and Morely JE. Ghrelin-induced feeding is dependent on nitric oxide. Peptides, 24: 913-918. 2003.

Gompertz B. On the nature of the function expressive of the law of human mortality, and on a new mode of determining the value of life contingencies. Philosophical Transactions of the Royal Society, 2: 513-585. 1825.

Granevitze Z, Hillel J, Feldman M, Six A, Eding H and Weigend S. Genetic structure of a wide-spectrum chicken gene pool. Animal Genetics, 40: 686-693. 2009.

Harper AE, Benevenga NJ and Wohlheuter RM. Effects of ingestion of disproportionate amounts of amino acids. Physiological Reviews, 50: 428-558. 1970.

Hegstedt DM, Briggs GM, Elvehjem CA and Hart EB. The role of arginine and glycine in chick nutrition. Journal of Biological Chemistry, 140: 191-200. 1941.

Hussein SM and Harms RH. Effect of amino acid deficiencies on yolk: albumen ratio in hen eggs. Journal of Applied Poultry Research, 3: 362-366. 1994.

Hutt FB and Nesheim MC. Changing the chick's requirement of arginine by selection. Canadian Journal of Genetics and Cytology, 8: 251-259. 1966.

Jahanian R. Immunological responses as affected by dietary protein and arginine concentrations in starting broiler chicks. Poultry Science, 88: 1818-1824. 2009.

Keshavarz K and Fuller HL. Relationship of arginine and methionine in the nutrition of the chicks and the significance of creatine biosynthesis in their interaction. Journal of Nutrition, 101: 217-222. 1971a.

Keshavarz K and Fuller HL. Relationship of arginine and methionine to creatine formation in chicks. Journal of Nutrition, 101: 855-862. 1971b.

Khajali F and Wideman RF. Dietary arginine: metabolic, environ- mental, immunological and physiological interrelationships. World's Poultry Science Journal, 66: 751-766. 2010.

Kwak H, Austic RE and Dietert RR. Influence of dietary arginine concentration on lymphoid organ growth in chickens. Poultry Science, 78: 1536-1541. 1999.

Kwak H, Austic RE and Dietert RR. Arginine-genotype interactions and immune status. Nutrition Research, 21: 1035-1044. 2001.

Leeson S. Potential of modifying poultry products. Journal of Applied Poultry Research, 2: 380-385. 1993.

Lieboldt MA, Halle I, Frahm J, Schrader L, Baulain U, Henning M, Preisinger R, Dänicke S and Weigend S. Phylogenic versus selection effects on growth development, egg laying and egg quality in purebred laying hens. European Poultry Science, 79: DOI: 10.1399/eps.2015.89. 2015.

Liu G, Dunnington EA and Siegel PB. Correlated responses to longterm divergent selection for eight-week body weight in chickens: growth, sexual maturity, and egg production. Poultry Science, 74: 1259-1268. 1995.

Lorenzoni AG and Ruiz-Fera CA. Effects of vitamin E and Larginine on cardiopulmonary function and ascites parameters in broiler chickens reared under subnormal temperatures. Poultry Science, 85: 2241-2250. 2006.

Lyimo CM, Weigend A, Msoffe PL, Eding H, Simianer H and Weigend S. Global diversity and genetic contributions of chicken populations from African, Asian and European regions. Animal Genetics, 45: 836-848. 2014.

Miller LL, Siegel PB and Dunnington EA. Inheritance of antibody response to sheep erythrocytes in lines of chickens divergently selected for 56-day body weight and their crosses. Poultry Science, 71: 47-52. 1992.

Mirkena T, Duguma G, Haile A, Tibbo M, Okeyo AM, Wurzinger $\mathrm{M}$ and Sölkner J. Genetics of adaptation in domestic farm animals: A review. Livestock Science, 132: 1-12. 2010.

National Research Council (NRC). Nutrient Requirements of Poultry. Revised Edition. National Academy Press. Washington D.C. 1994.

Nesheim MC and Hutt FB. Genetic Differences among White Leghorn Chicks in Requirements of Arginine. Science, 137: 691-692. 1962.

Nesheim MC. Kidney arginase activity and lysine tolerance in strains of chickens selected for a high or low requirement of arginine. Journal of Nutrition, 95: 79-87. 1968.

Rauw WM, Kanis E, Noordhuizen-Stassen EN and Grommers FJ. Undesirable side effects of selection for high production efficiency in farm animals: a review. Livestock Production Science, 56: 15-33. 1998.

Roland DA. I. Effect of dietary manipulation of protein, amino acids, energy, and calcium in aged hens on egg weight, shell weight, shell quality, and egg production. Poultry Science, 59: 2038-2046. 1980a.

Roland DA. II. Effect of dietary manipulation of protein, amino acids, energy, and calcium in young hens on egg weight, shell weight, shell quality, and egg production. Poultry Science, 59: 2047-2054. 1980b.

SAS Institute Inc. SAS for Windows. Version 9.4. Cary, NC, USA. 2012.

Simopoulos AP. Genetic variation and dietary response: Nutrigeneties/ nutrigenomics. Asia Pacific Journal of Clinical Nutrition, 11: 117-128. 2002.

Srinongkote S, Smriga M and Toride Y. Diet supplied with L-lysine and L-arginine during chronic stress of high stock density normalizes growth of broilers. Journal of Animal Science, 75: 
339-343. 2004.

Statsoft. Statistica for the Windows ${ }^{\mathrm{TM}}$ operating system. Version 12.0. StatSoft Inc. Tulsa, Oklahoma. 2014.

Tamir H and Ratner S. Enzymes of arginine metabolism in chicks. Archive for Biochemistry and Biophysics, 102: 249-258. 1963.

Tan J, Liu S, Guo Y, Applegate TJ and Eicher SD. Dietary Larginine supplementation attenuates lipopolysaccharideinduced inflammatory response in broiler chickens. British Journal of Nutrition, 111: 1394-1404. 2014.

Tan X, Sun WD, Li JC, Pan JQ and Wang XL. Changes in pulmonary arteriole protein kinase c-alpha expression associated with supplemental L-arginine in broilers during cool temperature exposure. British Poultry Science, 47: 230-236. 2006.

Tayade C, Jaiswal TN, Mishra SC and Koti M. L-arginine stimulates immune response in chickens immunized with intermediate plus strain of infectious bursal disease vaccine. Vaccine, 24: 552-560. 2006.

Van der Waaij EH. A resource allocation model describing consequences of artificial selection under metabolic stress. Journal of Animal Science, 82: 973-981. 2004.

Vogt H. WPSA - energy estimation formula. Working group No. 2 'Nutrition' of the European Federation of WPSA. Report of the Meeting. World's Poultry Science Journal, 42: 189-190. 1986.

Wang C, Zheng AJ, Xie M, Huang W, Xie JJ and Hou SS. Hypothalamic protein profiles associated with inhibited feed intake of ducks fed with insufficient dietary arginine. Animal, 8: 1113-1118. 2014a.

Wang C, Hou SS, Huang W, Xu TS, Rong GH and Xie M. Arginine affects appetite via nitric oxide in ducks. Poultry Science, 93: 2048-2053. 2014b. 